\title{
Farmstead drinking water sources, concerns and safety practices of livestock farm families in southern Alberta, Canada
}

\author{
M. Acharya ${ }^{1}$, R. G. Kalischuk ${ }^{1}$, K. K. Klein ${ }^{1} \&$ H. Bjornlund ${ }^{1,2}$ \\ ${ }^{I}$ Department of Economics and School of Health Sciences, \\ University of Lethbridge, Canada \\ ${ }^{2}$ University of South Australia, Adelaide, Australia
}

\begin{abstract}
The province of Alberta, like other provinces in Canada, has made considerable progress in increasing supply of good quality water for domestic use and consumption. However, the quality of rural drinking water in southern Alberta has received considerable attention in recent years because of intensive agricultural activities, livestock density, floods and the highest incidence of $E$ coli $\mathrm{O} 157: \mathrm{H} 7$ infection in the country. In fact relevant literature indicates that the region's water sources have high concentration levels of nitrate and/or coliform bacteria that exceed drinking water guidelines thus threatening the health of local farmers and residents. Little information is available on the farmstead drinking water safety practices of livestock farm families in southern Alberta so an inperson survey of feedlot farm families was carried out in Lethbridge Northern Irrigation District (LNID), one of the 13 irrigation districts located in southern Alberta. All respondents strongly agreed that access to safe and clean drinking water is essential for human and animal health and performance and they indicated that they use multiple water sources to avoid health problems. Other drinking water safety practices included the use of bottled water and/or home water treatment technologies for human consumption and the use of LNID monitored irrigation water for feedlot operations and gardens. Regarding the type of home water treatment technology used, a majority (over 70\%) used filtered water for cooking, drinking and washing. Only $9 \%$ used the city water supply for domestic purposes and $6 \%$ depended on the LNID water supply. It was interesting to note that $66 \%$ were concerned about their local water source and $67 \%$ were concerned about waterborne illnesses and $45 \%$ of respondents reported that they tested their water quality annually.

Keywords: rural drinking water, water quality, water safety practices, water testing, home water treatment systems, feedlot farm families, southern Alberta, Canada.
\end{abstract}




\section{Introduction}

Safe drinking water supply is a quality of life issue [1]. While $20 \%$ of the world's drinking water is in Canada, the province of Alberta accounts for only $2.2 \%$ of Canada's fresh water [2]. This is particularly important in terms of quality and quantity of drinking water as it can have consequences on water consumption for human and animal activities and for protection of large quantities of good quality water. These activities will be affected if the sources of water supplies are contaminated [3-5]; also poor access to good quality water may affect public health [6, 7]. In addition, Charrois and associates (2004) suggest that complacent attitudes towards drinking water quality may also lead to compromised disinfection practices as noted in such episodes as Walkerton (Ontario) and North Battleford (Saskatchewan) in May 2000 and April 2001, respectively [8]. Therefore, the first priority for drinking water consumers must be not only to improve access to good quality water [7], but also to ensure microbial safety [8]. This "multi-barrier approach" to drinking water safety generally begins with source protection, followed by a systematic development, installation and evaluation of treatment technologies for contaminant removal and monitoring [9].

The government of Alberta, like other provincial governments in Canada [10, 11], has made considerable improvements in the provision of safe and clean drinking water for Albertans using this approach, which is also known as "source to tap" approach [12]. Examples of such processes are: the establishment of Water Management Operations, a regulatory body that plays a key role in the management of water in Alberta and is responsible for over \$5 billion of water management infrastructure, including more than 200 water management systems [3]; the Canada-Alberta Water Supply Expansion Program, a national water supply expansion program ensuring long-term access to ample supplies of high quality drinking water mostly for Alberta's agricultural and rural communities [12]; Guidelines for Drinking Water Quality for all Albertans [13]; Alberta Surface Water Quality Guidelines to ensure that all Albertans have a safe drinking water source for decades to come [14]; and Water for Life Strategy a public outreach and consultation process to ensure that the province has safe supplies of water [15].

Alberta was the first province in Canada to adopt regulations in the Guidelines for Canadian Drinking Water Quality [16] and rural drinking water quality in southern Albert has received considerable attention in recent years. This seems mostly due to environmental concerns, livestock density and microbial contamination rates. Studies suggest that the region's poor water quality is associated with intensive agricultural activities, including irrigation, confined livestock operations, climate conditions, ground water flows and rates of leaching [3, 17-19]. A five-year surface water assessment study conducted by Saffran (2005) of the Oldman River Basin, the region's primary water source, found that this river has a high nitrate and coliform bacteria concentration that exceeds Canadian drinking water guidelines at all levels throughout the year [20]. Similarly, Rodvang et al. (2004), in a study of ground water quality in an 
irrigated area of southern Alberta, observed that shallow ground water discharges cause nitrate and chloride levels in the Oldman River to increase by factors of at least 4.3 and 1.3, respectively, with more significant effects in smaller streams and under low-flow conditions [19]. Southern Alberta, which is primarily known for its dry land farming combined with an elaborate field crop irrigation system, also has the highest incidence of $E$ coli $\mathrm{O} 157: \mathrm{H} 7$ contagion in the country $[17,21]$. This epidemiological evidence is a critical matter for public health and the quality of life for local residents, especially for south western rural communities that generally depend on treated irrigation water for their own and their livestock's consumption [3, 19]. Furthermore, the quality of drinking water supplies is a concern for non-health-related uses, including agricultural needs as poor quality water can impair watering systems [4, 22, 23]. Recent data from Alberta indicates that $67 \%$ of farm water supplies are not tested regularly (more than once every 2 years or not at all) [4] and $40 \%$ of Alberta's farmstead families have one or more home treatment devices [23], hence risking drinking and household use suitability. Surprisingly little information is available on the drinking water safety practices of livestock farm families living in southern Alberta, a critical group, that accounts for about $50 \%$ of Canada's beef supplies [24].

This paper presents the results of a survey of feedlot farm families' water use that was conducted in southern Alberta between September and December, 2005 to: (1) study the feedlot farm families' sources of farmstead drinking water supply and utilization patterns; (2) determine their drinking water concerns; and (3) identify and analyze their drinking water safety practices.

\section{Study site description}

This study was undertaken in the northern part of the Oldman River Basin, one of three watersheds in Alberta that are used for irrigational purposes [25]. This river basin has an area of $28200 \mathrm{~km}^{2}$, and services nine of the thirteen irrigation districts in the province of Alberta $[2,20,25]$. In particular, it supports the Lethbridge Northern Irrigation District (LNID), the second largest irrigation district in southern Alberta and the site of this study [25-27]. LNID's water distribution system is $650 \mathrm{~km}$ in length and is spread between the towns of Fort MacLeod and Turin [25]. The LNID services over 52,600 ha of cultivated lands, pastures and feedlot farm dugouts through diked and mostly lined open canals and pipelines to reduce seepage and contamination [20, 27]. The farm dugouts are commonly located close to the watercourse. They are either built on a higher elevation or are diked with compacted subsoil to a level $0.6 \mathrm{~m}$ higher than water level [28)], to prevent seepage loss under the dike and overtopping of the dike from wave action [26], while also preventing contaminated water from entering the storage facility. The district has return flow channels to carry excess irrigation water back to the river or reservoir, drop structures built at intervals to stabilize the water flow profile, and built-in-check structure to raise and hold water at specific levels and facilitate upstream delivery [29]. Gates are used to open and close turnouts and other diversionary structures and trash screens are used to keep gates from clogging [26]. The district also supplies thousands of 
people with water for domestic use [5]. Consequently, LNID's well advanced irrigation system has fostered growth in livestock and food processing industries as well as socioeconomic development in the area [17, 24, 27, 29].

LNID is home to 160 livestock owners with 219 operations, which includes 80 feedlot operators with 92 operations [26]. Moreover, almost half of those operations are large beef producers that are concentrated in the northern part of this district known as the "Feedlot Alley" [24]. Studies show that one feedlot may have as many as 25,000 cattle $[19,24]$. The sheer size of these operations and the livestock density has raised questions about environment, drinking water quality and threats to public health $[8,17]$. It is, therefore, timely to explore the feedlot farm families farmstead drinking water safety practices while residing in this area.

\section{Method}

An in-person survey was carried out between September and December 2005. Questions included domestic and feedlot water use practices, including sources of drinking water supply and storage facilities employed by the feedlot farm families. In addition, questions were asked that pertained to drinking water concerns and safety practices. Finally, demographic and farm specific questions (e.g., gender, age, marital status, education, place of birth, family composition, employment status, size and type of farming operation, number of animals fed per year) were included for background information.

Following pre-testing of the structured survey questionnaire, face-to-face interviews were carried out in every respondent's home. All feedlot families on a list provided by the staff of LNID were contacted by telephone and asked if they would participate in the study. While there are 80 feedlot operators in the district, the irrigation office provided a contact list of 64 potential respondents. Four duplicate names were removed from this prepared list. Data were collected from all who consented to the face-to-face interview: a total of 33 farm families who owned and operated feedlots were interviewed. The interviews averaged between 1 and 2 hours in length. All interviews were coded into an Excel spreadsheet for frequency distributions of variables, and analyses of the respondents' sources of drinking water supply as well as drinking water concerns and safety practices.

\section{Results}

\subsection{Feedlot farm families' sources of farmstead drinking water supply and utilization patterns}

Like previous studies $[1,3,7,10,11,14]$, this study found that all respondents strongly agreed that access to safe and clean drinking water is essential for human and animal health, and for non-health related activities such as water treatment facilities. Although all respondents acknowledged that they live in a moisture deficit region in Alberta with the Oldman River drainage basin being the principal source of water for most human activities of the area $[20,25]$, a large proportion of respondents $(66 \%)$ believed that access to safe and clean water was not a concern within the region. Most believed that the area has an 
ample supply of clean water. To identify the source(s) of farmstead drinking water supply system, respondents were asked to describe their source of drinking water for farmstead consumption. While the majority believed that the region has an abundant quantity of clean water, it appears that all used multiple sources to access this natural resource for their farmstead consumption purposes. Irrigation canal water provided by the LNID was the most common source followed by commercially sold drinking water $(58 \%)$, well or spring water $(21 \%)$, municipal water systems $(9 \%)$ and hauled water $(6 \%))$. Furthermore, results show that there were variations in drinking water supply consumption pattern. For instance, while $58 \%$ of respondents used commercially sold bottled water for human consumption, 91\% used treated irrigation water for animal watering and other feedlot uses, and $94 \%$ for garden and crop production purposes.

\subsection{Feedlot farm families' farmstead drinking water concerns}

Figure 1 illustrates the most important drinking water concerns of feedlot farm families. Most in this study believed that the region has clean water yet water quality was the most important concern for the respondents, as opposed to quantity of drinking water. When asked to describe the types of drinking water quality concerns, it was observed that, like earlier studies [4, 5,21 ], water pollution was the most important issue followed by the possible risk of contacting $E$ coli, farm waste management practices and animal health.

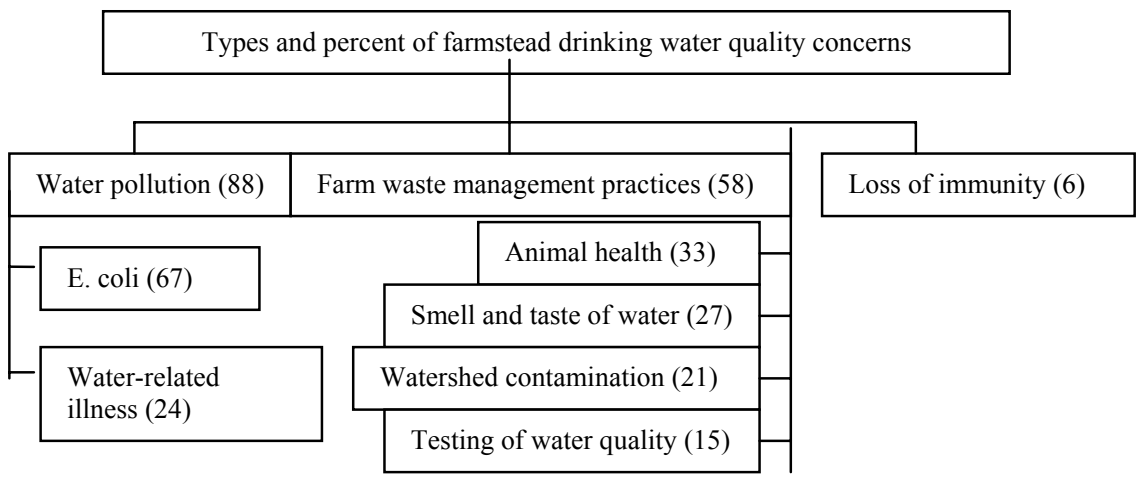

Figure 1: LNID feedlot farm families' drinking water quality concerns in 2005.

Though all respondents were knowledgeable about the public health and water contamination problems (i.e., both surface and ground water) associated with spraying concentrated faecal wastes from intensive livestock operation pits onto farm lands and watersheds [28], many (70\%) admitted disposing polluted 
water from their farm (lagoons and pens) through sprinkler/pivot systems onto the fields during heavy precipitation, particularly during floods [27].

\subsection{Feedlot farm families' farmstead drinking water safety practices}

In this study, the feedlot farm families were very much aware of being exposed to contaminated water in their daily lives and have adopted multiple-approaches to protect and preserve their drinking water from contamination. For instance, they not only described LNID managed irrigation water as their main source of drinking water, but a majority stored this treated water on their farm in dugouts that are built at a higher-elevation as well as diked, away from feedlot waste storage facilities as required by Alberta Agriculture [28]. All mentioned having one or more types of home water treatment devices to ensure clean and safe drinking water supply, unlike in the 1997 Alberta farmstead survey where only $40 \%$ indicated that they used home treatment devices [23]. Furthermore, they used the home water treatment devices to further clean routinely monitored irrigated water before using the water domestically. They believed that these devices make tap water microbiologically safer and/or cleaner to drink, cook, bathe and wash clothes. Some use it for aesthetic purposes.

The most common technologies utilized by the respondents were filters, reverse osmosis (RO), ultra violet light (UV), softeners and chlorination (Figure 2). Although home treatment filters were the most popular technology found in this study, its' water was limited to domestic use and human consumption. In short, the families interviewed indicated that home filtered water was used mostly for purposes such as cooking, improving taste, and sometimes for smell or appearance of their tap water. In contrast, none of the respondents mentioned boiling their water as a regular safety measure or conducting regular testing of home water treatment devices, while research suggests that all home treatment devices require regular maintenance to provide effective treatment $[4,22]$. More than half indicated that they use bottled water, which is not government monitored, for drinking and cooking purposes.

Only a minority of respondents (about 26\%) reported testing their farmstead drinking water more than once per year. This procedure is recommended by the province for rural water sources, particularly for surface water that is used for drinking and domestic use [16, 22]. In contrast, $45 \%$ reported testing water annually and the rest did intermittently as they seemed to need it. Agencies or services used for testing farmstead drinking water were: private laboratory $(45 \%)$, local health centre $(24 \%)$, local government services $(4 \%)$, County of Lethbridge, personal testing techniques (4\%) and unknown (9\%).

All respondents were knowledgeable of the negative impact contaminated water has on animal health; however, almost all believed that animals can consume a lot more contaminated water than humans. This finding replicates previous findings on animal water consumption patterns [28]. About half of the respondents said they had no alternate drinking water source besides the irrigation water for their feedlot animals. However, during heavy precipitation, almost all indicated that they turn off their irrigation reservoir intake until the irrigation canal is flushed by LNID, a procedure that is followed by the irrigation 
districts before opening the canals for summer operations every year [29]. In doing so, all believed that they are minimizing the risk of contaminated water intake by their livestock.

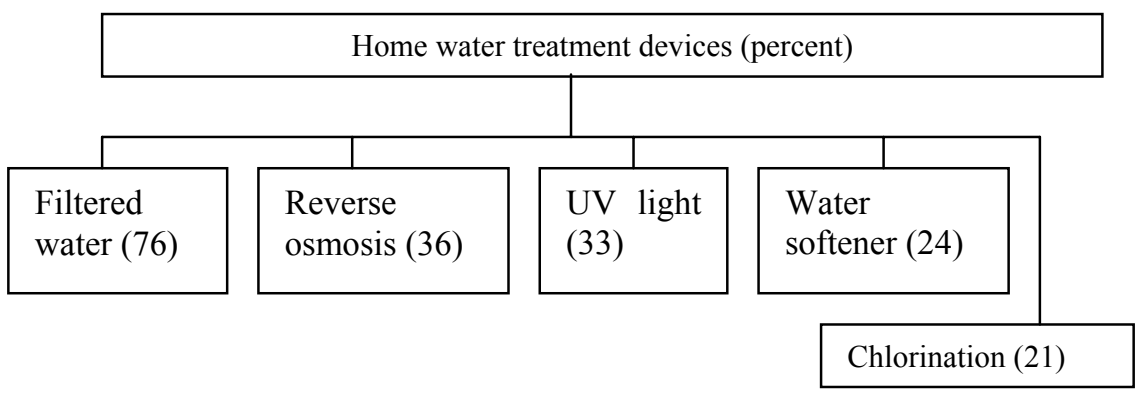

Figure 2: $\quad$ Types and percent of home water treatment devices used by LNID feedlot farm families at home as part of drinking water safety practices in 2005 .

\section{Discussion}

Safe and clean drinking water supply is essential for human and societal development $[1,2,5]$, and for good and improved health [3,7]. This is evident in the case of dry prone southern Alberta (Canada), the study area, where surface and ground water in the Oldman River basin support human, agricultural, recreational, social and economic activities. This region enjoys one of the most developed irrigated areas of crop agriculture combined with livestock farming, especially beef feedlot operations, in the province as well as in the country [3, 24]. It seems, however, that the agricultural development has created water quality challenges for people, such as the feedlot farm families, who reside in this region. Several water quality studies in southern Alberta have found that this region's watersheds have high level pesticide residues [20] and mention the prevalence of $E$ coli and Salmonella bacteria in the area's surface water [21]. Despite such reports, most respondents in the study believed that moisture deficit southern Alberta has ample clean water. However, all are aware of the possibility of contracting these concentrates in their drinking water and this knowledge seems to have influenced the respondents to protect and preserve their farmstead drinking water supply.

The findings in this study indicates the extent to which these perceived water pollution problems and concerns are linked to the development of drinking water safety practices among feedlot farm families residing in southern Alberta. For example, to prevent or minimize pollutants in the farmstead drinking water supply system, all respondents have adopted multiple-approaches to protect their drinking water supplies.

Although this study was limited to a single irrigation district - "LNID" - and one type of livestock farm family - feedlot farm families, the concern over water 
pollution and public health observed among respondents is consistent with recent national and international data [5, 7-9, 18]. It was observed that home water treatment devices are very popular among the respondents as a way to protect their water quality, even though most use LNID delivered treated irrigation water [26]. Corkal et al. [4] reported that over 4 million Canadians rely on private water supplies, therefore, they do not know whether or not their water sources are safe or suitable for any given use, including non-health-related uses. Therefore, many use home treatment devices to control water quality problem, not knowing there cleaning capabilities and output. Moreover, the scientists suggested that there is no legislation in Canada governing water treatment device, especially in the context of testing home treatment technology [22]. Similar information is also lacking in this farmstead study, while it is known that LNID and other Municipal water suppliers conform to Guidelines for Canadian Drinking Water Quality and disinfect all their water supplies [16, 22] as required by the province of Alberta [12]. Further research is needed before major conclusions can be drawn and recommendations made regarding home water treatment devices and farmstead drinking water quality control in Canada and elsewhere.

Finally, testing water quality on a regular basis is important for maintaining a safe and reliable source [5, 8, 13]. However, in this study, a majority of respondents test their water intermittently and none boil their tap water for human consumption as a preventive measure, unless they have had advisory from their local health authority. Unlike the 1997 rural Alberta farmstead survey where $40 \%$ of respondents indicated that they used some type of home water treatment system [23], in this study, all respondents mentioned that they used some type of home water treatment device to access safe and clean drinking water. In sum, the respondents believed that water treatment device is one of the important resources essential to protect and sustain their water supply, health, business, and be successful in life.

\section{Acknowledgements}

The authors thank the Alberta Ingenuity Centre for Water Research (AIWRC) for the financial support to carry out this research and the LNID office for providing the contact information of the feedlot farm families. We also thank all the respondents who gracefully and freely shared their experiences and perceptions with the interviewer.

\section{References}

[1] Association of Professional Engineers, Geologists and Geophysicists of Alberta (APEGGA), Drinking water quality in Alberta, Position paper, submission to Minister of the Environment, Edmonton, Alberta, pp. 1, 2003. 
[2] Alberta Government, Alberta water facts, 2008 http://albertawater.com/home/index.ph?option=com_content\&task=view\&i $\mathrm{d}=28 \&$ Itemi..

[3] Harras, T., Supply, quality and use of water in the prairie provinces, Kee Watin Publication, Regina, Saskatchewan, 2003.

[4] Corkal, D., Schutzman, W.C. \& Hilliard, C., Rural water safety from the source to the on-farm tap. Journal of Toxicology and Environmental Health, 26, pp. 1619-1642, 2004.

[5] Rush, R., Local water quality management in the Oldman river watershed. Guelph Water Management Group, University of Guelph (April 8), 2003.

[6] DesMeules, M., Pong, R., Lagacé, C., G, D., Manuel, D., Pitblado, R., Bollman, R., Guernsey, J., Kazanjian, A. \& Koren, I., How healthy are rural Canadians? Canadian population health initiative, Canadian Institute for Human Information, Ottawa, 2006.

[7] World Health Organization and Unicef, Water for life: Making it happen, WHO/UNICEF, Geneva, 2005.

[8] Charrois, J. W. A., Graham, D., Hrudey, S. E. \& Froese, K. L., Disinfection by-products in small Alberta community supplies. Journal of Toxicology and Environmental Health, 67(20/22), pp. 1797-1803, 2004.

[9] Watson, S. B. \& Lawrence, J., Overview - Drinking water quality and sustainability. Water Quality Research Journal of Canada, 38(1), pp. 313, 2003.

[10] Ontario Ministry of the Environment (OMOE), Clean Water Act, Toronto, Ontario, 2005.

[11] Government of Quebec, Quebec water quality, Quebec City, Quebec, 2002.

[12] Alberta Environment (AENV), Alberta environment's drinking water program, Edmonton, Alberta, 2007a.

[13] Alberta Environment (AENV), Water management operations, Edmonton, Alberta, pp. 1, 2007b.

[14] Western Economic Diversification Canada, Canada's new government and Alberta invest \$3.5 million to improve drinking water and bring major road improvement for southwest Alberta. Ottawa, Ontario, 2007. See also http://www.wd.gc.ca/77_4723_ENG_ASP.asp

[15] Alberta Environment (AENV), Water for life: Alberta's strategy of sustainability. Edmonton, Alberta, 2004.

[16] Alberta Government, Water quality testing: Drinking water. Edmonton, AB: Government of Alberta, 2006.

[17] Hyland, R., J. Byrne, Selinger, B., Graham, T., Thomas, J., Townshend, I. \& Gannon, V., Spatial and temporal distribution of faecal indicator bacteria in southern Alberta, Canada. Water Quality Research Journal of Canada, 38, pp. 15-32, 2003.

[18] Ivers, L. C. \& Ryan, E. T., Infectious diseases of severe weather-related and flood-related natural disasters. Current Opinion in Infectious Diseases, 19, pp. 408-414, 2006. 
[19] Rodvang, S. J., Mikalson, D. M. \& Ryan, M.C., Changes in ground water quality in an irrigated Area of Southern Alberta. Journal of Environmental Quality. 33, pp. 476-487, 2004.

[20] Saffran, K. A., Oldman river basin water quality initiative surface water quality summary report, Oldman River Basin Water Quality Initiative, Oldman Watershed Council and Government of Alberta, Edmonton, 2005.

[21] Health Canada, Notifiable diseases annual summary. Canada Communicable Disease Report, 27, pp. 2765, 2001.

[22] Canadian Water and Wastewater Association (CWWA), Municipal drinking water services, Guelph, Ontario, 2008. See http://www.cwwa.ca/faqmunicipal_e.asp

[23] Fitzgerald, D., Kiely, D., Neilson, D., Shaw, R., Audetta, S., Prior, R., Ashton, M. \& Allison, E., Alberta farmstead water quality survey. In Agricultural impacts on water quality in Alberta, vol. 1., Report \& Technical Report submitted to the Canada-Alberta Environmentally Sustainable Agriculture Agreement, 1997.

[24] Reader's Digest, Do you think agricultural runoff threatens our health? 2005, http://www.readersdigest.ca/debate.html? $\mathrm{a}=\mathrm{v} \& \mathrm{di}=123,19-11,2006$.

[25] Johnston, A., Floods in the Oldman river valley at Lethbridge, Sir Alexander Galt Museum, Lethbridge, Alberta, 1989.

[26] Acharya, M. P., Grant Kalischuk, R. Klein, K. K. \& Bjronlund, H., Do water contamination reports influence water use practices on feedlot farms and rural households in southern Alberta? Canadian Water Resources Journal, 32, pp. 1-14, 2007a.

[27] Acharya, M. P., Grant Kalischuk, R. Klein, K. K. \& Bjronlund, H., Health impacts of the 2005 flood events on feedlot farm families in southern Alberta, Canada, WIT Transactions on Ecology and the Environment, 103, 2007b.

[28] Alberta Agriculture, Food and Rural Development (AAFRD), Manure management for cow/calf producers: What is required by the Agricultural Operation Practices Act (AOPA), Government of Alberta, Edmonton, Alberta, 2005.

[29] Alberta Irrigation Projects Association (AIPA), Irrigation in the $21^{\text {st }}$ century. Volume 1: Summary report, Alberta Irrigation Association, Lethbridge, Alberta, 2002. 